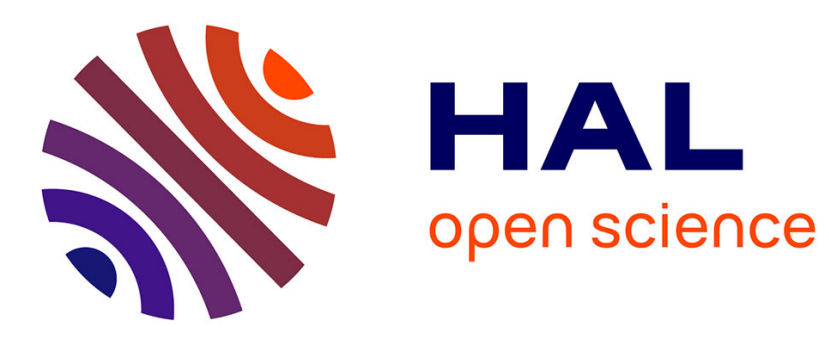

\title{
Traction forces of cancer cells
}

Valentina Peschetola, Valérie M. Laurent, Alain Duperray, Luigi Preziosi, Davide Ambrosi, Claude Verdier

\section{To cite this version:}

Valentina Peschetola, Valérie M. Laurent, Alain Duperray, Luigi Preziosi, Davide Ambrosi, et al.. Traction forces of cancer cells. Computer Methods in Biomechanics and Biomedical Engineering, 2011, 14 (S1), pp.159-160. 10.1080/10255842.2011.593954 . hal-00618952

\section{HAL Id: hal-00618952 https://hal.science/hal-00618952}

Submitted on 4 Sep 2011

HAL is a multi-disciplinary open access archive for the deposit and dissemination of scientific research documents, whether they are published or not. The documents may come from teaching and research institutions in France or abroad, or from public or private research centers.
L'archive ouverte pluridisciplinaire HAL, est destinée au dépôt et à la diffusion de documents scientifiques de niveau recherche, publiés ou non, émanant des établissements d'enseignement et de recherche français ou étrangers, des laboratoires publics ou privés. 


\title{
Traction forces of cancer cells
}

\author{
V. PESCHETOLA †\#, V. LAURENT $\dagger$, A. DUPERRAY $\$ \$$, L. PREZIOSI\#, \\ D. AMBROSI $\#^{\circ}$ and C. VERDIER $* \dagger$ \\ † CNRS-Univ. Grenoble I, UMR 5588, LIPhy, 38041 Grenoble, France \\ ‡ INSERM U823, Grenoble, France \\ \$ Univ. Grenoble I, Faculté de Médecine, Institut d'oncologie/développement, Albert Bonniot et \\ Institut Français du sang, UMR-S823, Grenoble, France \\ \# Matematica, Politecnico di Torino, Italy \\ - Mox, Politecnico di Milano, Italy
}

Keywords: Migration; motility; adhesion; integrins; forces

\section{Introduction}

Cell motility of cancer cells is a fundamental problem, and requires precise correlation between cell adhesive and rheological properties. The migration of cancer cells is studied in two dimensions, as cells are seeded onto functionnalized polyacrylamide gels. They migrate by developping focal adhesion sites and modulate their cytoskeleton dynamics by regulating actin and myosin.

This research aims at understanding the forces developped by different cancer cells of moderate to high invasiveness in order to investigate their contractility as well as the adhesion molecules necessary for cell migration.

\section{Methods}

The method proposed for the investigation of traction forces consists in preparing gels with embedded fluorescent beads inside. The technique was described previously by Dembo [1] and consists in solving an inverse elasticity problem starting from the beads displacement at the surface of gels, and get the stresses exerted by the cells. A new method has been development and confirmed experimentally by Ambrosi et al. [2] where the inverse problem is reduced to minimization of an energy functional; this reduces the problem to solving PDEs for the total displacement and stresse field. Assuming that most of the gel displacements are located within a thin gel thickness close to the upper surface, a 2D Finite element method solver is then used to obtain stresses.

Stress maps can then be obtained and the stresses exerted by the cancer cells range between [0-250 $\mathrm{Pa}$ ], depending on substrate stiffness.

Two types of cancer cells have been used. The first line is T24 [2], an epithelial invasive cancer cell line from bladder cancer. The second one is RT112, which is similar but less invasive.

A complementary tool is used to correlate the forces with the actual microscopic cytoskeleton dynamics involved in this adhesion/migration process, indeed cells which spread on a substrate develop focal adhesions and a corresponding actin network (coupled with myosin) is also shown to be present and linked to the focal adhesion zones. Thus double immunofluorescence was used in order to tag actin (the major cytoskeleton component), and paxillin (a molecule located within the focal adhesions), in order to investigate the correlation between forces, cytoskeleton, and focal adhesions.

\section{Results and Discussion}

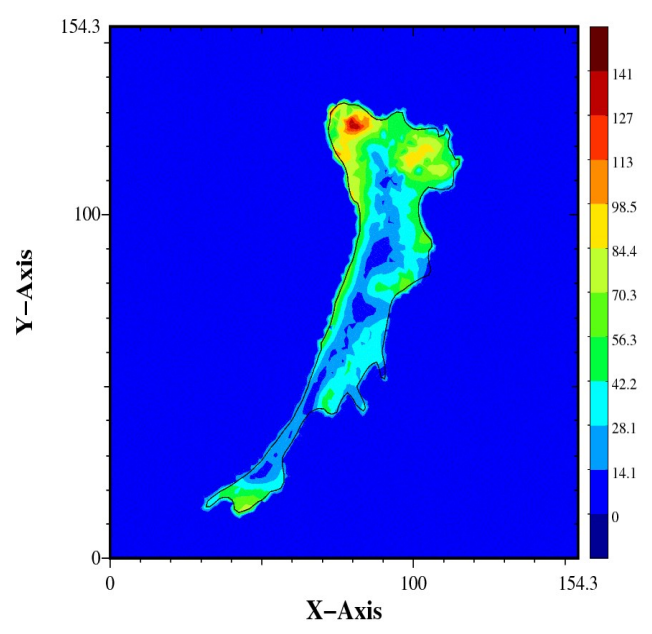

Figure 1: Forces exerted by a T24 cancer cell on a soft polyacrylamide substrate $(\mathrm{E}=10 \mathrm{kPa})$. Maximum stress is $150 \mathrm{~Pa}$.

*Corresponding author. Email: claude.verdier@ujf-grenoble.fr 
We first present a typical image of traction forces exerted by a T24 cancer cell on a soft polyacrylamide substrate $(E=10 \mathrm{kPa})$ in Fig. 1. Other T24 cells have been observed on similar substrates and showed forces in a similar range. The larger forces exerted average to $135 \mathrm{~Pa}$, as measured for 9 different cells at twenty different times. Their velocity of migration is around 80 $\mu \mathrm{m} / \mathrm{s}$. They usually move in a mesenchymal type of motion, showing long protusions or lamelipodia, supported by the presence of focal adhesions. This is revealed by looking at immunofluorescence image in Fig. 2. showing a T24 cell adhering onto a $10 \mathrm{kPa}$ substrate. One can see clearly well developped adhesions (red) and a widespread actin cytoskeleton (green). This is typical of T24 invasive cells.

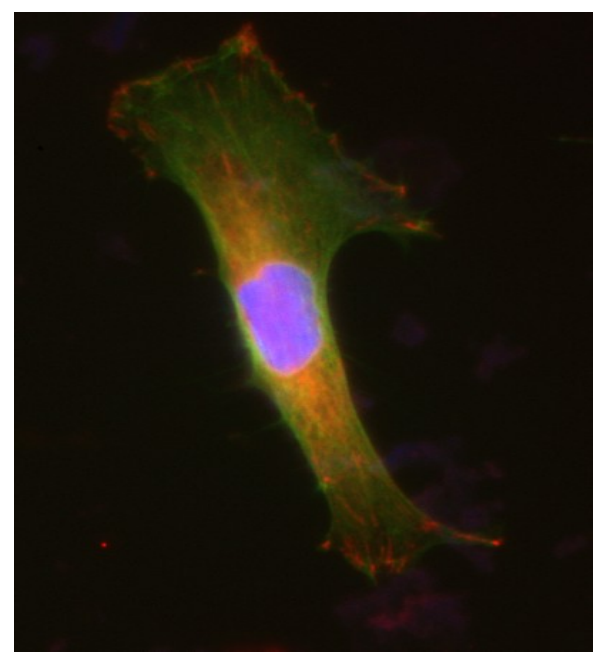

Figure 2: T24 cancer cell spread on a polyacrylamide substrate $(\mathrm{E}=10 \mathrm{kPa})$. Green is the actin cytoskeleton, whereas red represents the focal adhesions. The nucleus is in blue.

It is now important to compare the velocity of migration, the typical forces and the cytoskeleton dynamics for different invasive cells (i.e. more or less invasive).

RT112 cells (less invasive) show a different behavior. They usually do not spread as well and migrate (over an hour, as done in time-lapse experiments) slowly, with a typical speed of $20 \mu \mathrm{m} / \mathrm{h}$.

On the other hand, they develop larger forces to migrate: indeed, the forces exerted at the focal adhesions are usually around $175 \mathrm{~Pa}$ (in average) as compared to a value of $135 \mathrm{~Pa}$ found for the invasive cells (T24 line). Finally their motion looks more like an ameboid type of motion (more rounded shape) as compared to T24 cells.

Thus we may analyze this result in terms of the following:
- small traction forces are used when cells move faster (invasive cells)

- larger tractions are associated with slow cells (non invasive type)

This result does not seem to go with the effect of substrate rigidity as previously investigated $[2,3]$. Indeed one would expect to have a well spread cell to move slowly wheras we found that the well spread cell moves faster as compared to the other type. Then a possible mechanism could be the role of the myosin motors which link the actin cytoskeleton and are responsible for cell contraction. Possibly invasive cells can contract more and are able to pull their rear part (uropod) even when adhering well. Further work is now needed to investigate the flow of actin and myosin as such cells migrate.

\section{Conclusions}

To conclude, we have investigated different cancer cell lines from epithelial bladder cancer. Invasive cells develop smaller stresses on the substrate than less invasive cell, and move more rapidly. This effect can be attributed to an enhanced contractile behavior through the role of moysin which is an extra motor responsible for cell contraction. Further studies are under way, as well as the study of other cell types, to confirm these results.

\section{References}

[1] Dembo M. and Wang., Stresses at the cell-tosubstrate interface during locomotion of fibroblasts, Biophys. J., 76, 2307-2316 (1999).

[2] Ambrosi D., Duperray A., Peschetola V. and Verdier C., Traction pattern of tumor cells. J. Math. Biol., 58, 163-181 (2009).

[3] Lo C.M., Wang H.B., Dembo M. and Wang Y.L., Cell movement is guided by the rigidity of the substrate, Biophys. J., 79, 144-152 (2000)

\section{Acknowledgments}

This work was partly funded by the European Commission (EC) through a Marie Curie Research Training Network (MRTN-CT-2004-503661) entitled "Modeling, mathematical methods and computer simulation of tumor growth and therapy". Microscopy was performed at the microscopy facility of the Institut Albert Bonniot. This equipment was partly funded by the Association pour la Recherche sur le Cancer (Villejuif, France) and the Nanobio program. 